\title{
Translator in Systems. Some Notes on the Factors \\ Shaping Translations: the Case of Marta Sillaots and Young Estonia Publishing
}

With its origins in German culture, the term world literature always implicitly contains translation and does so in a double sense. Firstly, the term as such is a translation from German, and secondly, bigger portion of the literature of the world reaches the readers through translations. In this sense there is no separate emphasis needed to stress the importance of translation to the spread and development of world literature or any other field of knowledge.

But literary works do not travel from one cultural space to another by themselves. Such transfer of cultural goods is initiated by human agents for different reasons and purposes. Moreover, it is bound to publishing traditions and determined by multiple factors, economic ones among other things. Archival records in Estonian Literary Museum (ELM), letters exchanged between the translator and the publisher as well as translation contracts, reveal the mechanics of commissioning translations and the details pertaining to the translation process. By observing the correspondence between Marta Sillaots, an extremely prolific Estonian translator in the first half of the $20^{\text {th }}$ century, and the publishing house Young Estonia (Noor-Eesti Kirjastus) during the translation process of Mark Twain's The Adventures of Huckleberry Finn and Jules Verne's The Children of Captain Grant into Estonian, I will attempt to reveal some of the mechanics behind the formation of a fraction of Estonian translational canon of the 1930s. Although my research is a case study the centre of which is a particular translator with her particular translations, the focus of my paper is not the translator, but rather the systems around the translator that have an influence on when, what and in which manner some literary work is introduced into a culture, in other words, systems that can be held responsible for the design of the reading habits of whole generations in one language environment. Thus, my aim is to explore the conditioning factors of translation as a cultural and historical phenomenon, in other words, to view translation and translators in systems, as a part of a literary and social network. I will rather prefer the term system to describe the relations between different fields concerned in the production of a literary work over Itamar Even-Zohar's 
term polysystem $(1978 ; 2008$ [1990]). The dropping of the prefix poly-is much to do with Theo Hermans' reasoning in Translation in Systems (Hermans 2009). He argues that Even-Zohar's postulation about the dynamic and heterogeneous nature of a literary polysystem applies to cultural systems, literary among others, making the prefix redundant (Hermans 2009: 106). Thus, I will use the term polysystem only when referring to Even-Zohar's polysystem theory.

There is a long-standing tradition of viewing translation as an individual activity, implicitly holding the translator to be the key figure responsible for the whole process of transfer. Such a tradition comprises researches that compare the original to the translation and continues after the so called cultural turn in translation studies (Bassnett; Lefevere 1990), and following the wave inspired by Lawrence Venuti's invisibility of the translator (Venuti 1995; 2002; 2008), exemplified by the researches into the position of the translator in comparison to, for example, that of the author. However, already a brief look into the history of translation or, as it is with world literature, book history, shows, that translation is rarely an individual activity. Even if there is no such thing as a team of translators, there are the contributors to translation, a whole network of social agents, each of them with a certain preoccupation and interest: editors, proofreaders, and designers. Not to talk about the publishing companies that since their existence determine a great deal of what Gideon Toury, the most cited descriptive translation scholar, calls translation policy (Toury 2004: 209). Translation is indeed a process of negotiation in a double sense the least: a negotiation between the translator and the reader, but before the translated text actually appears, it is first and foremost a negotiation between the partners involved before the publishing of the translation. Such negotiations are often based on or involve economic factors.

The process by which a literary translation reaches the bookshelves varies very widely, but generally speaking, it has much to do with a certain translation policy, that is, to use Gideon Toury's words: “...the factors that govern the choice of text types or individual texts to be imported through translation into a particular language at a particular point in time." (Ib.) In Toury translation policy falls into a larger category of preliminary translation norms. It is a part of his norm theory that has found wide application in recent decades - norms as different social constraints that govern the decision making in the translation process and thus determine translational activity in a particular socio-cultural space at a particular point in time. Preliminary norms concern two factors - the directness of translation (whether the use of intermediary languages is tolerated in a particular culture at that particular point in time) and translation 
policy - what is to be translated. (Ib.) The area of preliminary norms does, however, connect translating to a more mundane world of finances, business plans and marketing issues. However, the economic area has not been a particularly abundant subject in translation studies so far. Anthony Pym in his introduction to Sociocultural Aspects of Translating and Interpreting points out the lack of studies in this field: "It is surprising, in this respect, how rarely economic factors are cited in our studies" (2006: 12). In recent years Gaby Thomson-Wohlgemuth (2006) and John Milton (2008) have, among other things, touched upon the issue of financial factors in translation production from the perspective of translation practices in East Germany and Brazil respectively.

I have chosen a small fracture of the publishing activity concerning the publication of literary translations in the 1930s in Estonia to be the focus of my paper because of a relatively stable translation policy of the period. The emphasis during 1930s was not on translated literature but rather on the original Estonian production, leaving translations to a somewhat peripheral position. According to Itamar Even-Zohar's polysystem theory translated literature can on certain conditions occupy central positions in the target culture's literary polysystem in comparison to the original production (2004: 200-201). According to Even-Zohar, these are usually the times of change in political terms, the times when new ideologies need to be imported and disseminated (ibid). In the case of Estonia the first decades of Soviet time are a good example of such a shift in centre - periphery. It is the time when a considerable change in translation norms occurred. According to Daniele Montichelli's ${ }^{1}$ (2010: 188) estimations, during the period of ten years prior to the Soviet occupation (1929-1939) translations made up $15 \%$ of the total book production in Estonia (ca 2450 translated books in total). To compare it to the situation 10 later, 1940-1954, the percentage of translation had grown from $15 \%$ to $48.5 \%$ (4919 translations in total). Thus, if, in accordance with Even-Zohar, the centrality of translation within a literary system is prone to grow during ideological changes, the relatively low percentage of translations in the 1930s in Estonia points to a rather stable situation. At the same time it is a period with clear state governed translation policy.

According to the documents available in the Estonian State Archive, state level national policies on what to translate were being devised already from 1919 onward, when a committee responsible for art and heritage under the

\footnotetext{
${ }^{1}$ Montichelli's data is, in turn, based on the works of Richard Antik, Uno Liivak and Enn Soosaar.
} 
Ministry of Education devised a preliminary plan for the translation of the classics of world literature. (Lott; Möldre 2007: 977) The same committee insisted on keeping the prises of translations as low as possible. (Ib.) Despite the economic recess at the beginning of 1930s the period can still be said to be quite fertile for translation, especially in terms of translation quality. Publishing houses often sought the advice of the Estonian literary elite of the time in the choice of books to be translated as well as engaged them in translating. State financed systems, loans and endowments, to support the publication of literature, among other things also literary translations, were in operation as well by 1930s. What concerns the importance of translations in the literary system of the time, then for example, the policy of Cultural Endowment ${ }^{2}$ was to support both translations of worthy pieces of world literature as well as original Estonian works. The amount of the support still tells us that original production was preferred: Cultural Endowment covered the costs of the honorarium for the translator whereas the originals were supported in the sum covering manuscript costs and printing costs. According to Aile Möldre and Mare Lott, bigger publication companies were preferred when it came to distributing the resources for translation publication, since the belief was that small private companies would not care for the quality of translation nor about book design, moreover, they would raise the price of the product in order to raise the profits. (Lott; Möldre 2007: 997) In other words, aesthetic and educational aims were kept in mind when devising the publication and translation policy. In addition to that low prices and thus also easy obtainability were the factors that were under consideration by the state officials when implementing translation policy.

The period of $1930 \mathrm{~s}$ is characterized by the translations of series of canonical works of world literature, publishing house Loodus, for instance gave out a series consisting of Nobel Prize laureates (50 books in total during 1934 1939). Also the list of translators-authors was impressive. Well-known Estonian writers were engaged in translating works of world literature. For example Friedebert Tuglas, at the peak of his career, translated Aleksis Kivi's The Cobblers on the Heath (Nõmmekingsepad), (1934, published by Estonian Literary Society), and A. H. Tammsaare translated Dostojevski's Crime and Punishment (1939, Loodus), etc.

\footnotetext{
2 Estonian Cultural Endowment $(1925-1941 ; 1994 \ldots)$ is a state financed organization created for the supporting and funding of different Estonian cultural enterprises, original literary production as well as translations among other things.
} 
Young Estonia Publishing was not the biggest of the publishing houses in the 1930s, but it was a prominent one, introducing new original Estonian literature as well a series of translations of the masterpieces of world literature. It was a forward thinking company, established by the literary formation by the same name. The company tried to balance between the profits and a mission. Young Estonia belonged to the list of the houses that got state benefits in form of reasonable loans and subsidies. Marta Sillaots, a well-known translator, author and literary critic by 1930s had a long relationship with this particular publishing house. The correspondence between her and Young Estonia Publishing available in EKM (Eesti Kirjandusmuuseum = Estonian Museum of Literature) to publish two translations in the series meant for young readers is telling of the translational situation, the factors that influenced translation process as well as of the translational norms of the time. The translations under observation are Mark Twain's The Adventures of Huckleberry Finn ${ }^{3}$ and Jules Verne's Les Enfants du Capitaine Grant. The first one to be translated for Young Estonia was Huck Finn, the negotiations between the publishing house and Marta Sillaots, the translator, started in May 1931.

27 May 1931 the publishing house sends Sillaots Huck Finn's original, so we can assume that the translation process starts from the end of May. According to the letters, requirements from the publishing house included a definite number of lines -11.000 and a request to translate the material by the month of August the same year. This left the translator two months for the translation. The contract shows that the translator was to get 4 cents per line of translated text, which was quite a satisfactory sum paid for translations of literary works at the time, for example, another well-known publishing house of the time Loodus paid less -3 cents per line. On July 7 Sillaots sends Young Estonia Publishing the first half of the translation and asks to read the proofs: ".. if at all possible" (EKM 92: 276: 26, p 21). According to the letters stored in the archive of the EKM, by August 5, Sillaots had sent in the rest of Huck Finn, which means that the she really did translate this novel into Estonian with more or less two months.

The next project with the same publishing house was Jules Verne's The Children of Captain Grant. The talks about publishing Verne started in November 1931, the initiative came from the publishing company. At first Sillaots herself suggests that Verne's novel is slightly outdated, but she maintains that it still merits translation (EKM 92: 276: 26, p 29). From the

${ }^{3}$ Hereinafter referred to as Huck Finn. 
correspondence it becomes clear that the translator would have preferred to translate something else instead, but apparently she did not want to jeopardize a potentially rewarding translation project, or risk with not being offered anything from the same company any more if she turned down a translation. Sillaots also suggests a list of other novels to the publishing house that according to her would be worthwhile to translate keeping in mind the development of the literary taste of the young readers, novels that according to her would be more interesting and educating. For instance, she suggests $\mathrm{C}$. Dickens's Little Dorrit and some of R. Kipling's novels. In December 1931 August Pill, the representative of Young Estonia publishing house, notifies Sillaots that the company will consider her suggestions, but they are still keen on Verne's novel. He gives their reasons: the narrative is engaging and gives an overview of geography, nature and the people of far away countries. (EKM 92: 276: 26, p 32) Alas, despite the fact that Sillaots tried to avoid major cuts and abbreviations in the translation, the publishing house insisted on the shortening of the text by one fourth. It evidently acted on the experience, since the full length translation of Verne's Mysterious Island (1929) was not selling. The correspondence shows the difference of opinion between the translator and the publishing house on what can be considered educational. Sillaots kept in mind literary aims but the publishing house was concentrating more on the factual knowledge the novel abounded with. The correspondence also shows the power relations between the parties, the translator as an adviser whose advice was heard but not always followed. Young Estonia publishers kept an eye on the translation process as well, made suggestions as to the translation of certain terminology etc. There is evidence of a committee inside the publishing house that monitored the publishing of literature for young readers. This committee, responding to the translator's request to translate the novel in full length advises to cut the amount of lengthy descriptions. A letter to Sillaots says: "The Children of Captain Grant will not lose anything by the omissions of all the unnecessary descriptions but on the contrary - no doubt, the omissions will raise the artistic value of the book. Even whole chapters of the book could be omitted, but this is not advisable since it might destroy the structure of the narrative." (EKM 92: 276: 26, p 39) The actual decision on what to omit was left to the translator. The contract for this translation is made up on 3 cents per line that is one cent less than Sillaots got for Huck Finn just months earlier from the same company. A letter explaining the cuts in the payment says: "we are forced to lessen the amount paid for the translator in order to make the ends meet and not raise the price of the book." (EKM 92: 276: 26, p 35) The cuts in 
the payment as well as the omissions and prescribed number of lines points to the centrality of economic factors in translation policy, as does the wish to keep the costs of the book reasonably low.

To conclude with, these examples may point to several things and raise several issues concerning historical research in general as well as the 1930s in Estonia in particular. First of all, what was the role of the intended target audience, the young readers, in the process of these particular translations? Do the educational aims, referred to in the correspondence between the translator and the institution point to a certain translation pattern or policy for the young readers? Nevertheless, when considering literary translations to the young Estonian readers in 1930s it is apparent from the negotiations between the translator and the publishing house that factual knowledge passed in a playful manner through appropriate fictional narrative was given preference over the issues of literary style and the style of the author of the original. Whether the intolerance for descriptions we often encounter nowadays is universal or is it connected to a canon of such gapped translations, will be difficult to prove. Another thing is that although the case of these particular translations may point us the general direction for further research, it is clear that in researching translation history a broader base than one case study is needed for any generalizations. Nevertheless, we can say that on the particular occasion described above the translator was an agent, an active participant in a complex exchange, a person with a particular experience but only a certain amount of power and with private and public interests to look after. Hence, it is the preliminary norms closely connected to the economic factors, deadlines and payment issues that heavily contributed (or even determined) the particular translational situation.

\section{References}

Bassnett, S.; Lefevere, A. 1990. Translation, History and Culture. London \& New York: Pinter.

Hermans, T. 2009 [1999] Translation in Systems. Manchester: St. Jerome Publishing.

Even-Zohar, I. 2008 [1990]. The Position of Translated Literature within the Literary Polysystem. - L.Venuti (ed). The Translation Studies Reader. London \& New York: Routledge, 199-204.

Even-Zohar, I. 1978. Papers in Historical Poetics. Tel Aviv: Porter Institute for Poetics and Semiotics.

Lott, M.; Möldre, A. 2007 Raamatukirjastamise toetamine Eesti Vabariigis 1918- 1940, Keel ja Kirjandus 12, 2007, 976-989. 
GIELEN

Milton, J. 2008. The importance of economic factors in translation publication. - Anthony Pym, Miriam Schlesinger, Daniel Simeoni (eds.) Beyond Descriptive Translation Studies: Investigations in Homage to Gideon Toury. Amsterdam: Benjamins, 163-173.

Montichelli, D. 2011. 'Totalitarian Translation' as a Means of Forced Cultural Change: The Case of Postwar Soviet Estonia. - Antoine Chalvin, Anne Lange, Daniele Montichelli (eds.) Between Cultures and Texts. Entre les cultures at les textes. Frankfuri am Main. Berlin. Bern. Bruxelles. New York. Oxford. Wien: Peter Lang, 187-200.

Pym, A. 2006. On the Social and the Cultural in Translation Studies - Anthony Pym, Miriam Schlesinger and Zuzana Jettmarova (eds.) Sociocultural Aspects of Translating and Interpreting. Amsterdam: Benjamins, 137-141.

Thomson-Wohlgemuth, G. 2006. Translation from the point of view of the East German censorship files. Anthony Pym, Miriam Schlesinger and Zuzana Jettmarova (eds.) Sociocultural Aspects of Translating and Interpreting. Amsterdam: Benjamins. 53 - 64.

Toury, G. 1995. Descriptive Translation Studies and Beyond. Amsterdam-Philadelphia: John Benjamins.

Toury, G. 2004. The Nature and Role of Norms in Translation. - Lawrence Venuti (ed.) The Translation Studies Reader. 205-218.

Archival sources from Estonian Literary Museum (EKM):

EKM, F 92: 276: 26. O/Ü “Noor-Eesti Kirjastus” ja Marta Sillaotsa kirjavahetus 06.09.1918-04.01.1938.

EKM, F 92: 277: 1. O/Ü “Noor-Eesti Kirjastus” ja Marta Sillaotsa kirjavahetus 25.01. 1926-15.10.1936. 